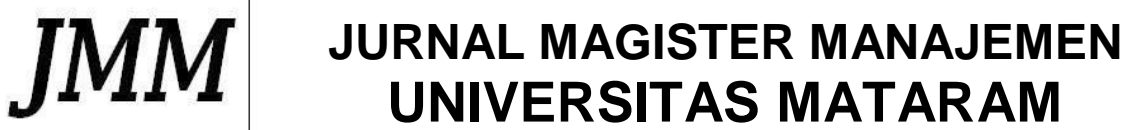 \\ UNRAM VOL. 6 No. 1 MARET 2017
}

\section{PERAN MEDIASI MOTIVASI DALAM PENGARUH TUNJANGAN KINERJA DAN KEPEMIMPINAN TERHADAP PRODUKTIVITAS (STUDI PADA PEGAWAI KOMISI PEMILIHAN UMUM KABUPATEN/KOTA SE-PULAU LOMBOK)}

\author{
Zinnurain ${ }^{1}$ \\ Thatok Asmony ${ }^{2}$ \\ Hermanto $^{3}$
}

\begin{abstract}
This study aims to determine the effect of performance benefits to the motivation and leadership, and leadership performance benefits to productivity, motivation effect on productivity, the impact on the productivity performance benefits through the mediation of motivation, as well as the influence of leadership on productivity through mediation motivation. The survey respondents are all civil servants Regency / City Lombok island numbered 97 people. But filling questionnaire answers just as much as 87 people. Data analysis techniques in this study conducted by SmartPLS 3... . As a result, the leadership performance benefits and positive and significant impact on the motivation; allowances and leadership performance and no significant positive effect on productivity; motivation positive and significant effect on productivity; performance benefits positive and significant impact on productivity through the mediation of motivation; leadership and significant positive effect on productivity through mediation motivation.
\end{abstract}

Keywords: performance benefits, leadership, motivation and productivity

\section{PENDAHULUAN}

Handoko (2001) mengemukakan bahwa kompensasi adalah segala sesuatu yang diterima para karyawan sebagai balas jasa untuk kerja. Mangkunegara (2002), mengemukakan bahwa insentif adalah suatu bentuk motivasi yang dinyatakan dalam bentuk uang atas dasar kinerja yang tinggi dan juga merupakan rasa pengakuan dari pihak organisasi terhadap kinerja karyawan dan kontribusi terhadap organisasi (perusahaan). Tunjangan kinerja berupa insentif diberikan kepada Pegawai Negeri Sipil (PNS) yang berkerja pada lingkup satuan kerja Komisi Pemilihan Umum (KPU). Tunjangan kinerja ini merupakan tunjangan yang diberikan sebagai fungsi dari keberhasilan pelaksanaan birokrasi reformasi yang didasarkan pada kelas jabatan dan prestasi kerja yang dicapai. Keputusan Sekretaris Jenderal KPU Nomor: 241/setjen/kpts/Tahun 2015.

Bila ditinjau dari sisi teori Tunjangan Kinerja atau insentif terhadap penigkatan motivasi dan produktivitas, maka akan terlihat hubungan yang kausalitas dan berpengaruh signifikan, sebagaimana dijelaskan oleh teori yang telah dipaparkan Mangkunegara (2002), bahwa insentif adalah suatu bentuk motivasi. Penjelasan teori tersebut juga didukung oleh sejumlah

\footnotetext{
${ }^{1}$ Mahasiswa Program Magister Manajemen Pascasarjana Universitas Mataram.

${ }^{2}$ Dosen Pembimbing Utama, Dosen Program Magister Manajemen Pascasarjana Universitas Mataram.

${ }^{3}$ Dosen Pembimbing Pendamping, Dosen Program Magister Manajemen Pascasarjana Universitas Mataram.
} 


\section{JURNAL MAGISTER MANAJEMEN
UNIVERSITAS MATARAM

penelitian yang menunjukkan hasil yang sama dan menguatkan teori, sebagaimana penelitian yang telah dilakukan Ojeifo, Ekpudu dan Jonathan (2014), bahwa pemberian insentif keuangan berpengaruh positif dan signifikan terhadap peningkatan motivasi yang mampu membentuk sikap serta semangat kerja.

Taraf signifikansi antara hubungan insentif dengan produktivitas yang tinggi selain telah dijelaskan oleh teori juga dari sejumlah hasil penelitian. Salah satunya adalah penelitian yang dilakukan Hakim (2011) bahwa kompensasi berpengaruh positif dan signifikan terhadap peningkatan produktivitas kerja pegawai, kompensasi dan motivasi secara simultan juga berpengaruh positif dan signifikan terhadap produktivitas kerja pegawai. Namun berbeda dengan Achie dan Kurah (2016), mengungkapkan bahwa meskipun karyawan menikmati beberapa insentif keuangan, namun karyawan masih tidak puas dengan insentif keuangan yang diberikan meski berpeluang untuk meningkatkan produktivitas. Dua penelitian ini terlihat jelas perbedaan yang ditunjukkan keterpengaruhan dari variabel insentif terhadap produktivitas

Kepemimpinan adalah proses untuk memengaruhi orang lain, untuk memahami dan setuju dengan apa yang perlu dilakukan dan bagaimana tugas itu dilakukan secara efektif, serta proses untuk memfasilitasi upaya individu dan kolektif untuk mencapai tujuan bersama (Yukl 2005). Sementara menurut Robbins (2006), kepemimpinan merupakan kemampuan untuk memengaruhi suatu kelompok ke arah tercapainya suatu tujuan.

Beberapa peneliti mengemukakan terdapat pengaruh signifikan antara kepemimpinan dengan produktivitas, diantaranya: Chandra, Halil, Yudhia dan Kustiari (2015), menyimpulkan bahwa: Kepemimpinan berpengaruh signifikan terhadap produktivitas kerja karyawan. Namun salah seorang peneliti Chandra dan Prasetya (2015), megemukakan bahwa; kepemimpinan berpengaruh tidak signifikan terhadap produktivitas. Hasil penelitian yang dilakukan peneliti di atas tampak jelas perbedaanya pada pengaruh variabel kepemimpinan terhadap produktivitas. Tugas pimpinan KPU dalam memberikan motivasi sebagaimana diinstruksikan Ketua KPU Republik Indonesia kepada seluruh Pimpinan KPU Provinsi dan Kabupaten/Kota agar secara bergiliran menjadi Pembina uapacara bendera satu kali dalam satu bulan, maupun dalam kegiatan seremonial lainnya agar mengingatkan bawahan tentang tugas dan tanggungjawabnya serta terus memotivasi guna meningkatkan produktivitas kerja.

Motivasi merupakan bagian penting yang harus dimiliki oleh setiap individu dalam berupaya mencapai tujuan, baik secara perorangan maupun kolektif. Motivasi berasal dari kata motif yang diartikan sebagai daya upaya yang mendorong seseorang untuk melakukan sesuatu, (Sutrisno, 2014). Motif dapat dikatakan sebagai daya penggerak dari dalam dan di dalam subjek untuk melakukan aktivitas-aktivitas tertentu demi mencapai tujuan. Bahkan motif dapat diartikan sebagai kondisi internal (kesiapsiagaan). Sedangkan menurut Hasibuan (1999) motivasi adalah suatu perangsang keinginan dan penggerak kemauan bekerja sesorang karena setiap motif mempunyai tujuan tertentu yang ingin dicapai.

Menurut teori motivasi Herzberg's Two Faktor Theory sebagaimana diungkapkan Hasibuan (2005) bahwa yang ideal yang dapat merangsang usaha adalah peluang untuk melaksanakan tugas yang lebih membutuhkan keahlian dan peluang untuk mengembangkan kemampuan. Teori Herzberg yang menarik adalah bahwa bila para karyawan merasa puas dengan pekerjaannya, kepuasan itu didasarkan faktor-faktor yang bersifat intrinsik seperti keberhasilan mencapai sesuatu pengakuan yang diperoleh, sifat pekerjaan yang dilakukan, rasa tanggung jawab, kemajuan dalam karier, pertumbuhan profesional dan intelektual yang dialami oleh seseorang. Sebaliknya apabila para karyawan merasa tidak puas dengan pekerjaannya, ketidak puasan itu pada umumnya dikaitkan dengan faktor-faktor yang 


\section{JURNAL MAGISTER MANAJEMEN
UNIVERSITAS MATARAM UNRAM VOL. 6 No. 1 MARET 2017}

sifatnya ekstrinsik, artinya bersumber dari luar diri karyawan yang bersangkutan, seperti: kebijakan organisasi, pelaksanaan kebijakan yang ditetapkan, supervisi oleh manajer, hubungan interpersonal dan kondisi kerja

Upaya menuju produktif tersebut sesungguhnya telah dilaksanakan oleh pemerintah, salah satunya berupa peningkatan motivasi kerja pegawai dengan memberikan tunjangan kinerja dan peningkatan pengawasan serta pembinaan dari pimpinan. Bermental produktif dalam melaksanakan kegiatan merupakan salah satu asas penyelenggaraan pemilu yakni: efektif dan efesien. Siagian (2002), menjelaskan bahwa sumber daya manusia merupakan elmen yang paling setrategis dalam organisasi yang dapat menyebabkan pemborosan dan inefisiensi dalam segala bentuknya.

Mewujudkan PNS KPU yang produktif dengan menekan pemborosan dan inefisiensi ini, telah dilakukan upaya dengan memberikan perhatian khusus berupa tunjangan kinerja serta sejumlah upaya lainnya. Secara umum produktivitas merupakan hubungan keluaran (barang atau jasa) dengan masukan (tenaga kerja, bahan dan uang) dalam ukuran efisien, (Sutrisno, 2014). Definisi lain tentang produktivitas sebagaimana dikemukakan Tohardi (2002) adalah sikap mental, yang selalu mencari perbaikan terhadap apa yang telah ada. Suatu keyakinan bahwa seseorang dapat melakukan pekerjaan lebih baik hari ini daripada hari kemarin dan hari esok lebih baik dari hari ini.

Hasil penelitian tersebut diantaranya: seperti yang dilakukan Assagaf dan Dotulong (2015), yang menyimpulkan bahwa: 1) Motivasi secara parsial berpengaruh signifikan terhadap Produktivitas Kerja, 2) Disiplin, Motivasi, dan Semangat Kerja secara simultan berpengaruh signifikan terhadap Produktivitas Kerja. Berbeda dengan penelitian yang dilakukan Elqadri, Wardoyo dan Priyono (2015), bahwa motivasi tidak berpengaruh signifikan terhadap produktivitas kerja. Hasil penelitian yang dilakukan dua peneliti di atas memunculkan perbedaan hasil penelitian dari variabel yang ada. Perbedaan tersebut memungkinkan hasil yang tidak sama meski diberikan perlakuan yang sama.

Meningkatkan motivasi, produktivitas dan kinerja PNS KPU Kabupaten/Kota melalui Tunjangan Kinerja atau yang akrab disebut dengan tukin, sudah terlaksana dengan baik, meski perlu peningkatan hasil. Salah satu upaya peningkatan hasil tersebut adalah dengan meningkatkan fungsi pengawasan dan pembinaan dari pimpinan KPU di masing-masing satuan kerja. Meningkatkan fungsi pengawasan dari komisioner KPU tersebut adalah dengan mengisntruksikan kepada seluruh pimpinan KPU agar bekerja penuh waktu. Bekerja penuh waktu tersebut ditegaskan dalam surat Ketua KPU Republik Indonesia Nomor 315/KPU/VI/2016 (salinan suratnya terlampir). Supervisi dan pembinaan oleh pimpinan masing-masing satuan kerja ini diharapkan mampu meningkatkan motivasi dan produktivitas serta kinerja dari setiap PNS maupun pegawai honorer dalam rangka mencapai target yang telah ditetapkan sebelumnya.

\section{KEASLIAN PENELITIAN}

Keaslian penelitian ini dapat ditunjukkan oleh paradigma yang digunakan dan sekaligus mengkaji variabel-variabelnya. Paradigma yang dipilih adalah memposisikan tunjangan kinerja dan kepemimpinan sebagai stimulan atau dikenal dengan variabel eksogen. Selanjutnya sejumlah penelitian terdahulu yang memiliki kesamaan dan perbedaan dengan penelitian ini diantaranya: Salim dan Lumbanraja (2014) dengan judul Pengaruh Motivasi, Kepemimpinan Dan Disiplin Terhadap Produktivitas Kerja Pegawai Dinas Kehutanan dan Perkebunan Kabupaten Tapanuli Tengah, di mana penelitian ini menggunakan teknik sampel jenuh sebanyak 54 orang. Pengujian hipotesis di lakukan dengan analisis regresi linear berganda. Penelitian ini memiliki sejumlah unsur kesamaan, seperti kesaman dua variabel 


\section{JURNAL MAGISTER MANAJEMEN
UNIVERSITAS MATARAM

eksogen yakni motivasi dan kepemimpinan, begitu pula dengan variabel endogennya yakni produktivitas. Sementara perbedaannya adalah, teradpat perbedaan satu dari empat variabel, yakni variabel disiplin. Teknik analisa data penelitian ini yang menggunakan analisis regresi linier berganda juga berbeda dengan teknik analisa data yang dilakukan peneliti yakni dengan menggunakan smartPLS 3.0.

Penelitian lain yang dilakukan Suhardjo (2013) dengan judul Pengaruh Kepemimpinan dan Tambahan Penghasilan Pegawai (TPP) terhadap Kinerja Pegawai dengan Motivasi sebagai Variabel Intervening (Studi Kasus pada Pemerintah Kabupaten Sorong) juga mengandung sejumlah kesamaan dengan penelitian yang akan dilakukan peneliti; diantaranya: variabel independen kepemimpinan dam tambahan penghasilan pegawai atau kompensasi, dan motivasi sebagai variabel intervening, teknik sampling yang sama-sama menggunakan sampel jenuh teknik analisa data yang dilakukan peneliti yakni dengan menggunakan smartPLS 3.0. Sementara perbedaannya adalah penelitian ini menggunakan variabel dependen kinerja, sedangkan penelitian yang dilakukan peneliti adalah produktivitas.

\subsection{Tunjangan Kinerja}

\section{TINJAUAN PUSTAKA}

Tunjangan kinerja sebagaimana dijelasakan dalam Peraturan Presiden Nomor 189 Tahun 2014 adalah tunjangan yang diberikan sebagai fungsi dari keberhasilan pelaksanaan birokrasi reformasi yang didasarkan pada kelas jabatan dan prestasi kerja yang dicapai. Tunjangan kinerja diberikan kepada pegawai KPU ini sesuai dengan porsi tugas dan tanggung jawab yang diklasifikasi besarannya berdasarkan ketentuan yangberlaku.

Pelaksanaan Tunjangan Kinerja ini senada dengan definisi insentif secara teoritis, sebagaimana dijelaskan Rivai dan Sagala, (2011) insentif diartikan sebagai bentuk pembayaran yang dikaitkan dengan kinerja, sebagai pembagian keuntungan bagi karyawan akibat peningkatan produktivitas atau penghematan biaya. Sistem ini merupakan bentuk lain dari kompnsasi langsung diluar gaji dan upah yang merupakan kompensasi tetap, yang disebut kompensasi berdasarkan kinerja (pay for performance plan). Menurut Simamora (2006) insentif adalah tambahan kompensasi diatas atau diluar gaji atau upah yang diberikan oleh organisasi. Insentif menghubungkan penghargaan dan kinerja dengan memberikan imbalan kinerja tidak berdasarkan senioritas atau jam kerja (Wibowo 2011).

Pemaparan teoritis sebelumnya, menjelaskan tentang tunjangan kinerja sebagaimana diatur dalam regulasi dan keputusan pemerintah, serta penjelasana teoritis berupan insentif atau kompensasi yang dikemukakan sejumlah ahli. Dari itu, untuk menguji pengaruh tunjangan kinerjaa terhadap motivaasi dan produktivitas pada penelitian ini, ada sejumlah indikator yang dapat diambil dengan mengacu pada pemaparan teori sebelumnya, baik berupa teori hukum atau peraturan maupun petunjuk praktis tunjangan kinerja, diantaranya adalah sebagai berikut : bentuk tukin, sifat pemberian tunjangan kinerja, jumlah tukin merujuk pada keputusan sekretaris jendral KPU Nomor: 241/ setjen/kpts/Tahun 2015; sedangkan inovatif, (Rivai et.al 2011) dan (Simamora 2006).

\subsection{Kepemimpinan}

Definisi kepemimpinan secara luas meliputi proses memengaruhi dalam menentukan tujuan organisasi, memotivasi perilaku pengikut untuk mencapai tujuan, memengaruhi untuk memperbaiki kelompok dan budayanya. Selain itu juga memengaruhi interpretasi mengenai peristiwa-peristiwa para pengikutnya, pengorganisasian dan aktivitas-aktivitas 


\section{JMM

untuk mencapai sasaran, memelihara hubungan kerja sama dan kerja kelompok, perolehan dukungan dan kerja sama dari orang-orang di luar kelompok atau organisasi (Rivai, 2004).

Peran pemimpin sebagaimana dipaparkan sebelumnya ini berkaitan dengan tugas pimpinan KPU Kabupaten/Kota selaku penyelenggara pemilu yang dibantu oleh kesekretariatan sebagai mana dijelaskan dalam Undang-Undang Nomor 15 Tahun 2011 tentang penyelenggara pemilu. Pimpan KPU selain sebagai sumber informasi, juga sebagai penyambung antara karyawan yang satu dan lainnya, serta bertugas memutuskan hal yang tepat bagi program organisasi, serta memberikan rekomendasi atas penempatan dan penetapan Sekretaris dan jabatan fungsional lainnya.

Pimpinan KPU Kabupaten/Kota sebanyak 5 (lima) orang, terdiri dari 4 (empat) anggota dan 1 (satu) orang ketua yang merangkap anggota. Lima jajaran pimpinan KPU ini terbagi menjadi lima bagian, yakni Divisi Humas, Divisi hokum dan penindakan, divisi teknis penyelenggara pemilu, divisi sosialisasi program dan pembinaan SDM, serta divisi Logistik dan keuangan. Dalam menjalankan tugas dan wewenangnya pimpinan KPU ini bersifat kolektif kolegial. Pengambilan keputusan dilakukan melalui mekanisme rapat pleno yang minimal harus dihadiri oleh tiga orang pimpinan atau komisioner KPU Kabupaten/Kota.

Mengukur hubungan dan pengaruh kepemimpinan terhadap motivasi dan produktivitas, maupun mengukur hubungan kepemimpinan melalui mediasi motivasi pada penelitian ini, tentu mengacu pada landasan teori yang telah dipaparkan sebelumnya. Dari pemaparan tersebut, terdapat sejumlah indikator yang dipilih penulis, diantaranya adalah sebagai berikut:

a. Pemberian dan pembagian tugas bagi staf; rujukan UU 8 Tahun 2015

b. Perintah atau pengarahan, rujukan (Avolio et.al 1992) dan (Sutrisno 2014)

c. Memeberikan penghargaan dan hukuman, rujukan; (Siagian 1997)

d. Memberikan motivasi rujukan; (Sutrisno 2014)

e. Melakukan pengawasan rujukan; (Sutrisno 2014)

\subsection{Motivasi}

Motivasi berasal dari kata latin movere yang berarti dorongan atau daya penggerak. Menurut Sutrisno (2014) mengemukakan bahwa: kata motif, diartikan sebagai daya upaya yang mendorong seseorang untuk melakukan sesuatu. Hasibuan (2006) bahwa motivasi adalah pemberian daya pengerak yang menciptakan kegairahan kerja seseorang. Zainun (1979), mendefinisikan motivasi adalah serangkaian usaha untuk menyediakan kondisikondisi tertentu, sehingga seseorang mau dan ingin melakukan sesuatu dan bila ia tidak suka, maka akan berusaha untuk meniadakan atau mengelakkan perasaan tidak suka itu. Berdasarkan pembahasan tentang berbagai pengertian motivasi, maka dapat disimpulkan sebagaimana dipaparkan Sutrisno (2014), bahwa motivasi kerja melingkupi beberapa komponen yaitu:

1. Kebutuhan, hal ini terjadi bila seseorang individu merasa tidak ada keseimbangan antara apa yang dimiliki dan yang diharapkan.

2. Dorongan, dorongan merupakan kekuatan mental untuk melakukan perbuatan atau kegiatan tertentu.

3. Tujuan, tujuan merupakan hal yang ingin dicapai oleh individu.

Menurut teori ini motivasi sebagaimana diungkapkan Hasibuan (2005) bahwa yang ideal yang dapat merangsang usaha adalah peluang untuk melaksanakan tugas yang lebih membutuhkan keahlian dan peluang untuk mengembangkan kemampuan. Hasil 


\section{$J M M$ UNRAM

penelitian Herzberg yang menarik adalah bahwa bila para karyawan merasa puas dengan pekerjaannya, kepuasan itu didasarkan faktor-faktor yang bersifat intrinsik seperti keberhasilan mencapai sesuatu pengakuan yang diperoleh, sifat pekerjaan yang dilakukan, rasa tanggung jawab, kemajuan dalam karier, pertumbuhan profesional dan intelektual yang dialami oleh seseorang. Sebaliknya apabila para karyawan merasa tidak puas dengan pekerjaannya, ketidakpuasan itu pada umumnya dikaitkan dengan faktorfaktor yang sifatnya ekstrinsik, artinya bersumber dari luar diri karyawan yang bersangkutan, seperti: kebijakan organisasi, pelaksanaan kebijakan yang ditetapkan, supervisi oleh manajer, hubungan interpersonal dan kondisi kerja.

Pada penelitian ini, variabel motivasi selain sebagai variabel endogen dari variabel tunjangan kinerja dan kepemimpinan, serta sebagai variabel independen terhadap produktivitas, juga berperan sebagai variabel mediasi antara tunjangan kinerja dan kepemimpinan terhadap produktivitas. Sejumlah teori telah dipaparkan sebelumnya pada penelitian ini. Dari pemaparan yang sudah ada, penulis ingin mengembangkan Herzberg's Two Faktor Theory, yakni mengukur motivasi karyawan dengan tingkat kepuasan. Kepuasan yang dimaksud adalah dari aspek intrinsik dan ekstrinsik. Dari dua faktor inilah kemudian penulis membuat indikator penelitian yakni:

a. Penghargaan dan Pengakuan untuk faktor intrinsik;

b. Supervisi yang baik; Status dan tanggung jawab serta Peraturan yang fleksibel, adalah untuk faktor ekstrinsik (Hasibuan 2005).

\subsection{Produktivitas}

Produktivitas berasal dari kata produktif artinya sesuatu yang mengandung potensi untuk digali, sehingga produktivitas dapatlah dikatakan sesuatu proses kegiatan yang terstruktur guna menggali potensi yang ada dalam sebuah komoditi atau objek. Tohardi (2002) mengemukakan bahwa produktivitas kerja merupakan sikap mental. Suatu keyakinan bahwa seseorang dapat melakukan pekerjaan lebih baik hari ini dari pada hari kemarin dan hari esok lebih baik dari hari ini. Wibowo (2011), secara konseptual produktivitas adalah hubungan antara keluaran atau hasil organisasi dengan masukan yang diperlukan.

Menurut Mankiw (2006) produktivitas ditentukan oleh empat hal yaitu: modal fisik, modal manusia. sumber daya alam serta pengetahuan teknologi. Menurut Sinungan (2005) produktivitas dibatasi pada delapan faktor yang umum, yaitu: manusia, modal, metode/proses, produksi, lingkungan organisasi, lingkungan Negara, lingkungan Internasional serta Umpan Balik. Ndraha (2002) faktor-faktor yang memengaruhi produktivitas tenaga kerja yaitu: kualitas dan kemampuan fisik karyawan, sarana pendukung, serta supra sarana.

Mengukur variabel endogen produktivitas dari variabel eksogen tunjangan kinerja, kepemimpinan dan motivasi, serta hubungan tidak langsung yakni dari tunjangan kinerja dan kepemimpinan yang dimediasi variavbel motivasi, tentu harus memiliki indikator penilaian yang berikutnya akan dijabarkan dalam bentuk instrumen penelitian ini. Indikator dimaksud adalah bersumber dari pemaparan teori sebelumnya. Diantaranya adalah sebagai berikut: kemampuan personal dalam menyelesaikan tugas yang telah diberikan, rujukan Ndraha (2002), Sinungan (2005) dan Mankiw (2006); meningkatkan hasil yang dicapai dengan rujukan Sinungan (2005) serta mutu dan efisiensi dengan rujukan Simanjuntak (1998) dan (Wibowo 2011).

\section{KERANGKA KONSEPTUAL}




\section{$\int M M \quad \begin{gathered}\text { JURNAL MAGISTER MANAJEMEN } \\ \text { UNIVERSITAS MATARAM }\end{gathered}$

Berdasarkan penjelasan kajian pustaka dan tinjauan empirik maka kerangka pemikiran penelitian ini adalah untuk variabel eksogen yakni tunjangan kinerjadan kepemimpinan, sementara variabel endogen yaitu motivasi kerja dan produktivitas kerja. Pada penelitian ini motivasi kerja juga sebagai variable intervening. Dengan demikian paradigma dalam penelitian ini dapat digambarkan oleh kerangka pikir teori penelitian seperti berikut:

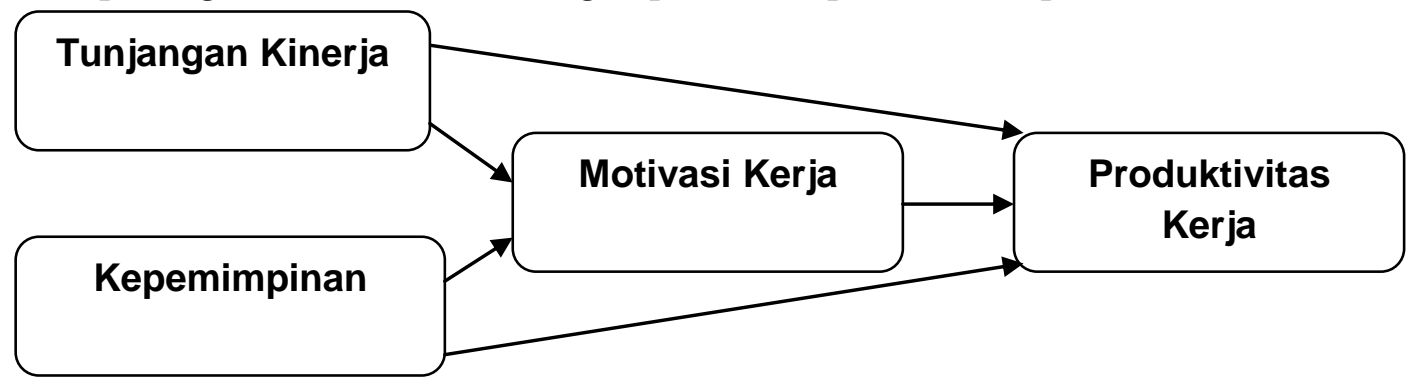

Gambar 1 Kerangka konseptual

\section{HIPOTESIS}

Hipotesis yang dapat diambil dari proposal penelitian ini, sebagaimana pemaparan pada latar belakang, landasan teori dan kerangka konseptual yang telah digambarkan pada bagan tersebut adalah sebagai berikut:

a. Diduga ada pengaruh yang positif dan signifikan dari Tunjangan Kinerja terhadap motivasi kerja pada pegawai KPU Kabupaten/Kota se-Pulau Lombok.

b. Diduga ada pengaruh yang positif dan signifikan dari Kepemimpinan terhadap motivasi kerja pada pegawai KPU Kabupaten/Kota se-Pulau Lombok.

c. Diduga ada pengaruh yang positif dan signifikan dari tunjangan kinerja terhadap Produktivitas kerja pada pegawai KPU Kabupaten/Kota se-Pulau Lombok.

d. Diduga ada pengaruh yang positif dan signifikan dari kepemimpinan terhadap Produktivitas kerja pada pegawai KPU Kabupaten/Kota se-Pulau Lombok.

e. Diduga ada pengaruh yang positif dan signifikan dari motivasi terhadap Produktivitas kerja pada pegawai KPU Kabupaten/Kota se-Pulau Lombok.

f. Diduga ada pengaruh yang positif dan signifikan dari tunjangan kinerja terhadap Produktivitas kerja melalui motivasi pada pegawai KPU Kabupaten/Kota se-Pulau Lombok.

g. Diduga ada pengaruh yang positif dan signifikan dari kepemimpinan terhadap Produktivitas kerja melalui motivasi pada pegawai KPU Kabupaten/Kota se-Pulau Lombok.

\section{METODE PENELITIAN}

Jenis penelitian yang digunakan dalam penelitian ini adalah kuantitatif kausal. Hubungan kausal adalah hubungan yang bersifat sebab akibat (Sugiyono, 2014). Penelitian ini bertujuan untuk mengetahui hubungan sebab akibat antara pengaruh pemberian tunjangan kinerja, kepemimpinan terhadap motivasi dan produktivitas kerja pada pegawai KPU Kabupaten/Kota se-Pulau Lombok. Teknik pengumpulan data yang digunakan dalam penelitian adalah adalah dengan pendekatan metode sensus. Jumlah anggota populasi sebanyak 97 orang yang tersebar di lima satker KPU Kabupaten/Kota se-pulau Lombok. Alat yang dipakai sebagai pengumpulan data untuk uji statistik dalam penelitian ini adalah kuisioner atau angket. Sementara alat untuk mengumpulkan data pendukung adalah dengan menggunakan wawancara dan dokumentasi. 


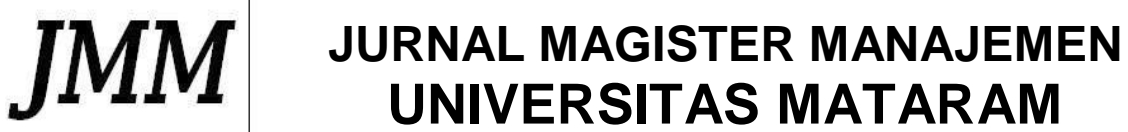

a. Analisis Deskripsi

Analisis deskripsi adalah analisis terhadap deskripsi dari gambaran umum tentang Pegawai di tiap satker KPU Kabupaten/kota se-pulau Lombok, tentang karakteristik responden, tanggapan responden, dan tentang variabel penelitian, yang bertujuan untuk menggambarkan secara lebih mendalam hasil dari data yang diperoleh.

b. SmartPLS 3.0

Pengujian dengan menggunakan pendekatan PLS akan dilakukan estimasi koefesienkoefesien jalur yang mengidentifikasi kekuatan dari hubungan antara variabel independen dan variabel dependen. Melakukan analsis dengan pendekatan PLS dalam penelitian ini akan dilakukan dengan dua tahap, sebagaimana dijelaskan (Noor, 2014) yakni:

1. Merancang Model Struktural (Inner Model)

2. Merancang Model Pengukuran (Outer Model)

Menurut Noor (2014), model pengukuran mendefinisikan setiap blok indikator berhubungan dengan variabel latennya. Melakukan analisis dengan metode PLS, Ghozali (2012) membagi model pengukuran tahapan analisis tersebut menjadi dua tahapan, yakni menilai model pengukuran dan struktural. Sementara untuk penilian model pengkuruan ini ada dua tahapan model pengukuran yang harus dilakukan, diantaranya:

a. Convergent validity dan discriminant validity. Model pengukuran Convergent validity akan dianggap cukup bila memiliki nilai anatara 0.5 sampai dengan 0.6, untuk jumlah indikator dari variabel laten yang berkisar antara 3 sampai 7 (Noor, 2014). Sedangkan menurut Ghozali (2012) model pengukuran dengan refleksif indikator dinilai tinggi bila berkorelasi lebih dari 0,7 dengan kosntruk yang diinginkan. Sementara, untuk mengukur discriminant validity dari pengukuran dengan indikator refleksif akan dinilai berdasarkan cross loading pngukuran dengan kosntruk. Adapun discriminant validity akan direkomendasikan bila nilai dari average variance extracted (AVE) lebih besar dari 0.50, Noor (2014).

b. Nilai ini menunjukan internal consistency yaitu nilai composite reliability yang tinggi menunjukan nilai konsistensi dari masing-masing indikator dalam mengukur konstruknya. Nilai CR diharapkan > 0.7, (Noor, 2014).

c. Uji hipotesis dilakukan pada alpha $5 \%$ indikator dengan penimbang terkecil ( $\mathrm{t}$-statistik > 1.96) (Noor, 2014). Selanjutnya nilai t-tabel tersebut dijadikan sebagai cut off untuk menerima atau menolak hipotesis yang diajukan. Kreteria penerimaan dan penolakan hipotesis ini dengan ketentuan sebagai berikut :

1. Jika nilai t-hitung $>\mathrm{t}$-tabel dengan taraf signifikansi 0.05 maka Ha diterima, yang artinya $\mathrm{H}_{0}$ ditolak.

2. Jika nilai t-hitung $<\mathrm{t}$-tabel dengan taraf signifikansi 0.05 maka H0 diterima, yang artinya Ha ditolak.

\section{Hasil Penelitian}

\subsection{Deskripsi Variabel Penelitian}

7.1.1. Tunjangan Kinerja

Pada variabel tunjangan kinerja ini terdiri empat indikator dengan sepuluh item pernyataan. Empat indikator tersebut yaitu bentuk tukin (item insturmen : 1, 2) memiliki nilai layak dengan skor rata-rata 3,8, sifat pemberian tunjangan kinerja (item insturmen : 3, 4) dengan skor rata-rata 3,6, jumlah tunjangan kinerja (item insturmen : 5, 6, 7) memiliki skor 3,8 dan inovasi/pengembangan diri (item insturmen : 8, 9, 10) memiliki skor 4.

\subsubsection{Kepemimpinan}




\section{JURNAL MAGISTER MANAJEMEN
UNIVERSITAS MATARAM

Sementara variabel kemepimpinan terdiri dari sepuluh item yang terbagi dalam empat indikator; Pemberian dan pembagian tugas bagi staf (item insturmen : 11,12) dengan skor 4, kemampuan mendistribusikan perintah atau pengarahan (item insturmen : 13, 14) dengan nilai 3,6, kemampuan memeberikan penghargaan dan hukuman (item insturmen : 15, 16) dengan nilai 3,4, kemampuan memeberikan motivasi (item insturmen : 17, 18) dengan skor 3,6 dan kemampuan melakukan pengawasan (item insturmen : 19, 20) dengan nilai 4,1. Dari 87 orang responden terhadap komponen variabel kepemimpinan yang merupakan tanggapan dan penilaian atas kepemimpinan pada satuan kerja lingkup KPU Kabupaten/Kota se-pulau Lombok memiliki nilai rata-rata 3,7 dengan kategori bagus.

\subsubsection{Motivasi}

Variabel motivasi terdiri atas 10 item pernyataan yang terangkup dalam lima indikator yakni, penghargaan (item insturmen : 21, 22), pengakuan (item insturmen : 23, 24) Supervisi yang baik; (item insturmen : 25,26), status dan tanggung jawab(item insturmen : 27, 28), serta peraturan yang fleksibel (item insturmen : 29, 30) menggambarkan motivasi kerja yang dirasakan oleh para responden pada satuan kerja lingkup KPU Kabupaten/Kota se-pulau Lombok.

Variabel motivasi kerja diukur dengan menggunakan lima indikator yakni; penghargaan yang memiliki nilai rata-rata 4,3 dengan kategori sangat tinggi, demikian juga dengan indikator dan suvervisi yang baik juga termasuk kategori sangat baik dengan skor indikator berturut 4,3 dan 4,5. Sedangkan peraturan yang fleksibel memiliki skor tinggi dengan nilai rata-rata 3,7. Sementara nilai rata-rata sebagai kreteria umum dari variabel motivasi ini adalah 4,2 dan tergolong sangat tinggi.

\subsubsection{Produktivitas}

Variabel produktivitas ini terdapat 10 item pernyataan juga sebagaimana variabel lainnya yang sudah dibahas pada bagian sebelumnya. Variabel ini menggambarkan produktivitas pegawai lingkup KPU Kabupaten/Kota se-pulau Lombok yang tampak jelas pada tiap indikator. Di mana indikator yang ada pada variabel produktivitas ini sebanyak tiga, yaitu; kemampuan personal dalam menyelesaikan tugas yang telah diberikan (item insturmen: 31,32, 33), meningkatkan hasil yang dicapai (item insturmen: 36, 38, 39, 40) serta mutu dan efisiensi (item insturmen: 34, 35, 37). Variabel produktivitas diukur dengan menggunakan tiga indikator yang diantaranya adalah kemampuan personal dalam menyelesaikan tugas yang telah diberikan yang memiliki nilai rata-rata 4,1 dengan kategori sangat tinggi. Sedangkan indikator meningkatkan hasil yang dicapai memiliki skor tinggi juga dengan nilai rata-rata 4. Demikian pula indikator mutu dan efisiensi mendapat skor 3,8 dengan nilai tinggi juga. Dengan demikian nilai rata-rata sebagai kreteria umum dari variabel motivasi ini adalah 4 dan tergolong tinggi.

\section{ANALISA DATA}

\subsection{Metode Outer Model atau Meansurement Model}

Tedapat tiga kriteria di dalam penggunaan teknik analisis data dengan SmartPLS untuk menilai Outer Model yaitu Convergent Validity, Discriminant Validity, dan Composite Reliability.

\section{1) Convergent Validity}

Convergent Validity dari model pengukuran dengan refleksif indikator berdasarkan korelasi antara item score atau component score yang diestimasi dengan software PLS. Ukuran refleksf individual dikatakan tinggi jika korelasi lebih dari 0,07 dengan variabel yang diukur, namun menurut Ghozali (2008) untuk penelitian tahap awal skala pengukuran nilai loading 


\section{$J M M$ UNRAM \\ JURNAL MAGISTER MANAJEMEN UNIVERSITAS MATARAM VOL. 6 No. 1 MARET 2017}

0,50 sampai 0,60 dianggap cukup memadai. Dalam penelitian ini akan digunakan batas loading factor sebesar 0,50.

\section{2) Discriminant Validity}

Discriminant validity dilakukan untuk memastikan bahwa setiap konsep dari masingmasing variabel laten berbeda dengan variabel lalinnya. Model dikatakan mempunyai discriminant Validity yang baik jika setiap nilai loading indikator dari sebuah variabel laten memiliki nilai loading yang lebih besar dibanding nilai loading jika dikorelasikan dengan variabel laten lainnya. Hasil pengujian discriminant Validity ditampilkan pada tabel berikut:

Tabel 1 Nilai Discriminant Validity

\begin{tabular}{|c|c|c|c|c|}
\hline Variabel & $\begin{array}{c}\text { Kepemimpinan } \\
(\mathrm{X} 2)\end{array}$ & $\begin{array}{c}\text { Motivasi Kerja } \\
(\mathrm{Z})\end{array}$ & $\begin{array}{c}\text { Produktivitas } \\
\text { Kerja }(\mathrm{Y})\end{array}$ & $\begin{array}{c}\text { Tunj. Kinerja } \\
(\mathrm{X} 1)\end{array}$ \\
\hline $\mathrm{X} 2.1$ & 0,862 & 0,480 & 0,383 & 0,369 \\
\hline $\mathrm{X} 2.2$ & 0,896 & 0,455 & 0,338 & 0,428 \\
\hline $\mathrm{X} 2.3$ & 0,849 & 0,391 & 0,373 & 0,386 \\
\hline $\mathrm{X} 2.4$ & 0,354 & 0,225 & 0,163 & 0,342 \\
\hline $\mathrm{X} 2.5$ & 0,469 & 0,364 & 0,368 & 0,560 \\
\hline Z1.1 & 0,213 & 0,379 & 0,191 & 0,258 \\
\hline Z1.2 & 0,456 & 0,795 & 0,533 & 0,362 \\
\hline Z1.3 & 0,472 & 0,828 & 0,631 & 0,258 \\
\hline Z1.4 & 0,239 & 0,575 & 0,343 & 0,268 \\
\hline Z1.5 & 0,423 & 0,743 & 0,616 & 0,396 \\
\hline Y1.1 & 0,215 & 0,612 & 0,873 & 0,251 \\
\hline Y1.2 & 0,328 & 0,511 & 0,717 & 0,329 \\
\hline Y1.3 & 0,549 & 0,545 & 0,721 & 0,308 \\
\hline X1.1 & 0,413 & 0,252 & 0,190 & 0,680 \\
\hline X1.2 & 0,584 & 0,433 & 0,372 & 0,844 \\
\hline X1.3 & 0,350 & 0,351 & 0,310 & 0,753 \\
\hline X1.4 & 0,370 & 0,268 & 0,232 & 0,744 \\
\hline
\end{tabular}

Sumber : Data Diolah

Berdasarkan pada tabel 1 di atas menunjukkan bahwa nilai loading dari masingmasing item terhadap konstruknya lebih besar dari pada nilai cross loadingnya. Dari hasil analisa cross loading tampak bahwa tidak terdapat permasalahan discriminant validity atau dengan kata lain dapat dikatakan data memiliki discriminant validity yang baik.

3)

Composite Reliability

Kriteria validity dan reabilitas juga dapat dilihat dari nilai reabilitas suatu variabel dan nilai average variance extracted (AVE) dari masing-masing variabel. Variabel dikatakan memiliki reabilitas yang tinggi juka composite reability diatas 0,07 dan AVE berada di atas 0,50.

Pada Tabel 2 Nilai Composite Reability

\begin{tabular}{|l|c|}
\hline \multicolumn{1}{|c|}{ Variabel } & Composite Reliability \\
\hline Tunjangan Kinerja (X1) & 0,843 \\
\hline Kepemimpinan (X2) & 0,831 \\
\hline Motivasi Kerja (Z) & 0,806 \\
\hline Produktivitas Kerja (Y) & 0,816 \\
\hline
\end{tabular}

Sumber : Data Diolah 


\section{$J M M$ UNRAM \\ JURNAL MAGISTER MANAJEMEN UNIVERSITAS MATARAM VOL. 6 No. 1 MARET 2017}

Tabel 2 menginformaskan bahwa seluruh variabel memenuhi composite reliability karena nilainya di atas angka yang direkomendasikan, yaitu di atas 0,70 yang berarti bahwa seluruh variabel sudah memenuhi kriteria realibel.

\subsection{Pengujian Model Struktural (Inner Model)}

Pengujian inner model atau model struktural dilakukan untuk melihat hubungan antara variabel, nilai signifikansi dan R-square dari model penelitian. Model struktural dievaluasi dengan menggunakan R-Square untuk variabel dependen, uji serta signifikansi dari koefisien parameter jalur struktural. Utnuk mendapatkan nilai uji masing-masing komponen tersebut dilakukan dengan melihat hasil proses bootstraping dan akan ditunjukkan nilai masing-masing konstruk untuk tiap parameter. Selain itu ditampilkan pula nilai hubungan antara masingmasing variabel, baik yang menunjukkan hubungan langsung maupun hubungan tidak langsung. Pada gambar model struktural berikut akan ditampilkan hasil olah data masingmasing indikator dan variabel serta nilai hubungannya .

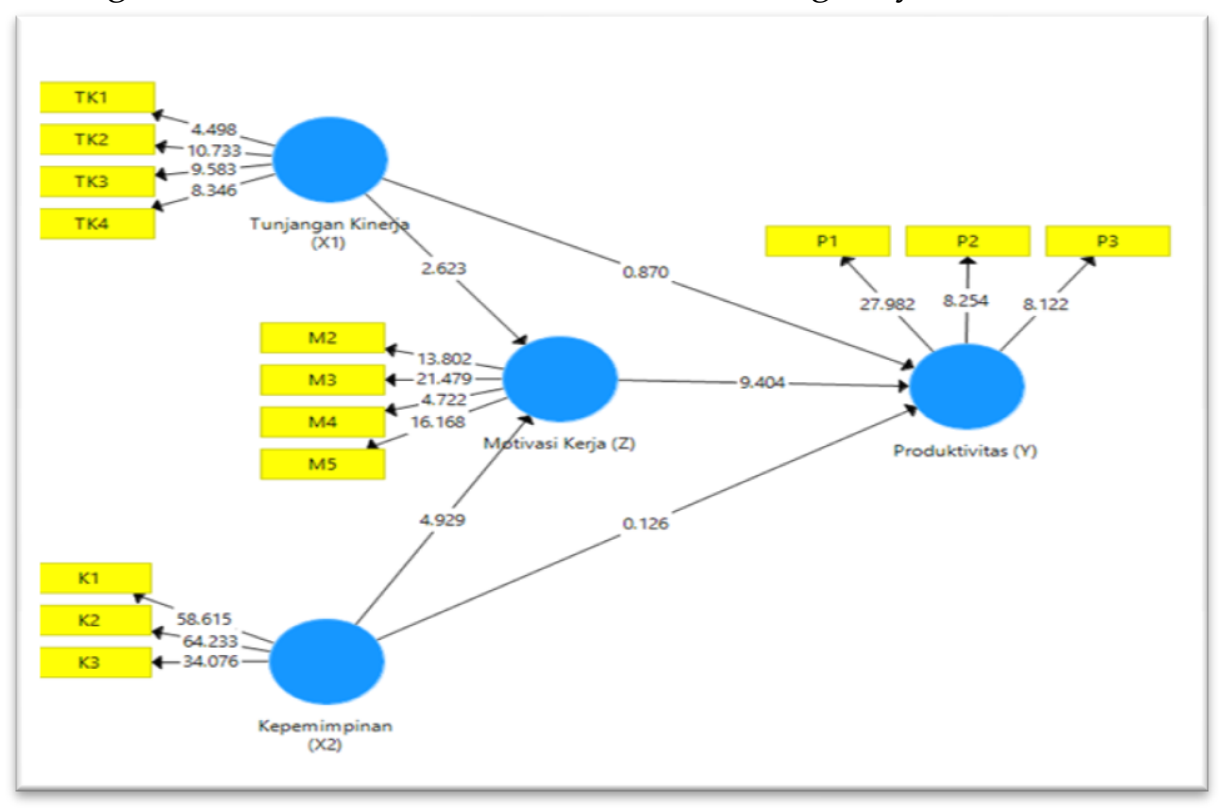

Gambar 3 Model Struktural Hasil Olah Data

Dari gambar 3 dapat dijelaskan bahwa covariance pengukuran indikator dipengaruhi oleh konstruk laten atau mencerminkan variasi dari konstruk unidimensional yang digambarkan dengan bentuk lingkaran dengan beberapa anak panah dari konstruk ke indikator. Model ini menghipotesiskan bahwa perubahan pada konstruk laten mempengaruhi perubahan pada indikator. Dalam model struktural tersebut terdapat dua variabel eksogen yaitu tunjangan kinerja, dan kepemimpinan, suatu variabel endogen mediasi atau antara yaitu motivasi kerja, serta satu variabel endogen terkait yaitu produktivitas kerja.

Penilaian model dengan PLS dimulai dengan melihat R-Square untuk setiap variabel laten depeden. Perubahan nilai R-Square dapat digunakan untuk setiap variabel laten dependen. Perubahan nila R-Square dapat digunakan untuk menilai pengaruh variabel laten eksogen tertentu terhadap variabel laten endogen yang mempunyai pengaruh substantif. Tabel 3 memperlihatkan hasil estimasi R-Square dengan menggunakan SmartPLS. 


\section{JMM UNRAM \\ VOL. 6 No. 1 MARET 2017}

Tabel 3 Nilai R-Square

\begin{tabular}{|l|c|}
\hline \multicolumn{1}{|c|}{ Variabel } & R-Square \\
\hline Motivasi Kerja (Z) & 0,306 \\
\hline Produktivitas Kerja (Y) & 0,534 \\
\hline
\end{tabular}

Sumber : Data diolah

Tabel 3 mengajukan nilai R-Square variabel motivasi kerja 0,306 dan produktivitas kerja 0,534. Semakin tinggi nilai R-Square, maka semakin besar kemampuan variabel eksogen tersebut dapat dijelaskan oleh variabel endogen sehingga semakin baik persamaan struktural. Untuk variabel motivasi kerja memiliki nilai R-Square sebesar 0,306 yang berarti 30,6 persen varian tunjangan kinerja dan kepemimpinan pada lingkup KPU Kabupaten/Kota se-pulau Lombok mampu dijelaskan oleh variabel motivasi kerja sedang sisanya dijelaskan oleh variabel lain di luar model penelitian. Variabel produktivitas kerja memiliki nilai R-Square 0,534 yang berarti 53,40 persen varian tunjangan kinerja dan kepemimpinan serta motivasi kerja mampu dijelaskan oleh variabel produktivitas kerja sedang sisanya dijelaskan oleh variabel lain di luar model penelitian.

\subsection{Pengujian Hipotesis}

Signifikansi parameter yang diestimasi memberikan informasi yang sangant berguna mengenai hubungan antara variabel-variabel penelitian. Dasar yang digunakan dalam menguji hipotesis adalah nilai yang terdapat pada output path coeffecients. Tabel 4 memberikan output estimasi untuk pengujian model struktural.

Tabel 4 Result for Path Coeffecients

\begin{tabular}{|l|l|l|l|l|l|}
\hline \multicolumn{1}{|c|}{ Variabel } & $\begin{array}{c}\text { Original } \\
\text { sample }\end{array}$ & $\begin{array}{c}\text { Standard } \\
\text { error }\end{array}$ & $\begin{array}{c}\text { T } \\
\text { statistics }\end{array}$ & $\begin{array}{c}\text { P } \\
\text { Values }\end{array}$ & Kesimpulan \\
\hline Tukin (X1)-> Motivasi Kerja (Z) & 0,265 & 0,280 & 0,100 & 2,655 & 0,008 \\
\hline $\begin{array}{l}\text { Kepemimpinan (X2) -> Motivasi } \\
\text { Kerja (Z) }\end{array}$ & 0,385 & 0,379 & 0,080 & 4,831 & 0,000 \\
\hline $\begin{array}{l}\text { Tukin (X1)-> Produktvitas Kerja } \\
(Y)\end{array}$ & 0,080 & 0,087 & 0,084 & 0,952 & 0,341 \\
\hline $\begin{array}{l}\text { Kepemimpinan (X2) -> } \\
\text { Produktivitas Kerja (Y) }\end{array}$ & 0,015 & 0,004 & 0,118 & 0,127 & 0,899 \\
\hline $\begin{array}{l}\text { Motivasi Kerja (Z) -> } \\
\text { Produktivitas Kerja (Y) }\end{array}$ & 0,684 & 0,691 & 0,072 & 9,494 & 0,000 \\
\hline
\end{tabular}

Sumber : Data Primer Diolah

Sementara untuk menguji hipotesis hubungan tidak langsung, akan ditampilkan hasil olah data PLS pada tabel berikut:

Tabel 5 Result for Indirect Effects

\begin{tabular}{|l|c|c|c|c|c|}
\hline Variabel & $\begin{array}{l}\text { Original } \\
\text { sample }\end{array}$ & $\begin{array}{l}\text { Standard } \\
\text { error }\end{array}$ & $\begin{array}{c}\text { T } \\
\text { statistics }\end{array}$ & $\begin{array}{c}\mathbf{P} \\
\text { Values }\end{array}$ & Kesimpulan \\
\hline $\begin{array}{l}\text { Tukin (X1)-> Motivasi Kerja (Z) } \\
->\text { Produktvitas Kerja (Y) }\end{array}$ & $\mathbf{0 , 2 6 4}$ & $\mathbf{0 , 2 6 2}$ & $\mathbf{0 , 0 6 2}$ & $\mathbf{4 , 2 6 9}$ & $\mathbf{0 , 0 0 0}$ \\
\hline $\begin{array}{l}\text { Kepemimpinan (X2) -> } \\
\text { Motivasi Kerja (Z) -> } \\
\text { Produktvitas Kerja (Y) }\end{array}$ & $\mathbf{0 , 1 8 2}$ & $\mathbf{0 , 1 9 5}$ & $\mathbf{0 , 0 7 5}$ & $\mathbf{2 , 4 2 3}$ & $\mathbf{0 , 0 1 6}$ \\
\hline
\end{tabular}

Sumber : Data Primer Diolah

Dari tabel hasil pengujian hipotesis langsung dan tidak langsung diatas, maka pengujian hipotesis dapat dilakukan sebagaimana ditampilkan pada tabel berikut: 
TMM JURNAL MAGISTER MANAJEMEN UNIVERSITAS MATARAM

UNRAM VOL. 6 No. 1 MARET 2017

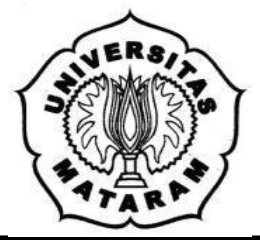




\section{JMM

Tabel 6 Uji hipotesis

\begin{tabular}{|c|l|l|}
\hline No. & \multicolumn{1}{|c|}{ Hipotesis } & \multicolumn{1}{|c|}{ Keputusan } \\
\hline $\mathbf{1 .}$ & $\begin{array}{l}\text { Hipotesis 1 menyatakan bahwa tunjangan kinerja berpengaruh positif } \\
\text { dan signifikan terhadap motivasi kerja. }\end{array}$ & $\begin{array}{l}\text { Positif dan } \\
\text { signifikan }\end{array}$ \\
\hline 2. & $\begin{array}{l}\text { Hipotesis 2 menyatakan bahwa kepemimpinan berpengaruh positif dan } \\
\text { signifikan terhadap motivasi kerja. }\end{array}$ & $\begin{array}{l}\text { Positif dan } \\
\text { signifikan }\end{array}$ \\
\hline 3. & $\begin{array}{l}\text { Hipotesis 3 menyatakan bahwa tunjangan kinerja berpengaruh positif } \\
\text { dan signifikan terhadap Produktivitas. }\end{array}$ & $\begin{array}{l}\text { Positif dan } \\
\text { tidak } \\
\text { signifikan }\end{array}$ \\
\hline 4. & $\begin{array}{l}\text { Hipotesis 4 menyatakan bahwa kepemimpinan berpengaruh positif dan } \\
\text { signifikan terhadap produktivitas kerja. }\end{array}$ & $\begin{array}{l}\text { Positif dan } \\
\text { tidak } \\
\text { signifikan }\end{array}$ \\
\hline 5. & $\begin{array}{l}\text { Hipotesis 5 menyatakan bahwa motivasi kerja berpengaruh positif dan } \\
\text { signifikan terhadap produktivitas kerja. }\end{array}$ & $\begin{array}{l}\text { Positif dan } \\
\text { signifikan }\end{array}$ \\
\hline 6. & $\begin{array}{l}\text { Hipotesis 6 menyatakan bahwa tunjangan kinerja berpengaruh positif } \\
\text { dan signifikan terhadap produktivitas kerja melalui motivasi kerja. }\end{array}$ & $\begin{array}{l}\text { Positif dan } \\
\text { signifikan }\end{array}$ \\
\hline 7. & $\begin{array}{l}\text { Hipotesis 7 menyatakan bahwa kepemimpinan berpengaruh positif dan } \\
\text { signifikan terhadap produktivitas kerja melalui motivasi kerja. }\end{array}$ & $\begin{array}{l}\text { Positif dan } \\
\text { signifikan }\end{array}$ \\
\hline
\end{tabular}

\section{PEMBAHASAN}

\subsection{Pengaruh Tunjangan Kinerja terhadap Motivasi Kerja}

Hasil analisis data menunjukkan tunjangan kinerja berpengaruh positif dan signifikan terhadap motivas kerja. Ini artinya tunjangan kinerja yang diukur melalui empat indikator yakni; bentuk tunjangan kinerja, sifat tunjangan kinerja, jumlah tunjangan kinerja dan inovatif, berpengaruh positif dan signifikan terhadap motivasi kerja. Hal ini memberikan petunjuk bahwa hipotesis diterima. Tujuan pemberian tunjangan kinerja kepada para pegawai KPU Kabupaten/Kota se-pulau Lombok yang berdanpak positif dan signifikan terhadap motivasi kerja adalah tercapai. Hal ini mengandung makna bahwa semakin tinggi dan meningkat tunjangan kinerja yang diterima pegawai KPU Kabupaten/Kota se-pulau Lombok maka motivasi kerja para pegawai tersebut akan meningkat.

Hasil penelitian ini sejalan dengan penelitian lain, seperti yang dilakukan oleh Bukhari (2016) bahwa insentif berpengaruh secara langsung terhadap motivasi kerja karyawan pada PT. Reza Perkasa Sidoarjo. Demikian pula dengan penilitian yang dilakukan oleh Ojeifo et.al (2014), bahwa pemberian insentif keuangan berpengaruh positif dan signifikan terhadap peningkatan motivasi yang mampu membentuk sikap serta semangat kerja. Sambiran, et,al (2015) menyimpulkan bahwa kepemimpinan secara parsial berpengaruh positif dan signifikan terhadap motivasi kerja; kepemimpinan dan insentif secara simultan berpengaruh positif dan signifikan terhadap motivasi kerja.

Peneliti lain, yakni Suhardjo, (2013) menyimpulkan bahwa kepemimpinan secara parsial berpengaruh positif dan signifikan terhadap motivasi kerja; kepemimpinan dan insentif secara simultan berpengaruh positif dan signifikan terhadap motivasi kerja. Endang, et. al (2013) menyimpulkan bahwa insentif finansial secara parsial berpengaruh positif dan signifikan terhadap motivasi kerja; insentif finansial dan insentif non finansial secara simultan berpengaruh positif dan signifikan terhadap motivasi kerja.

Sementara Mangkunegara (2002), menjelaskan bahwa insentif adalah suatu bentuk motivasi yang mampu meningkatkan smengat kerja dan inovasi karyawan. Insentif atau 


\section{JURNAL MAGISTER MANAJEMEN
UNIVERSITAS MATARAM UNRAM VOL. 6 No. 1 MARET 2017}

tunjangan kinerja juga merupakan bagian dari bentuk reward atau penghargaan atasan kepada staf atas keberhasilan dalam melaksanakan sejumlah program yang telah ditetapkan organisasi. Semangat pemeberian tunjangan kinerja oleh pemerintah sebagaimanan tertuang dalam Keputusan Sekretaris Jenderal KPU Nomor: 241/setjen/kpts/Tahun 2015 bahwa pemeberian tunjangan kinerja ini adalah sebagai fungsi dari keberhasilan pelaksanaan birokrasi reformasi yang didasarkan pada kelas jabatan dan prestasi kerja yang dicapai. Unsur penghargaan dan memotivasi pegawai lingkup KPU sebagai tujuan dan sasaran yang akan dicapai dari penerapan pemberian tunjangan kinerja ini dapat dibuktikan kerbhasilanya dalam penelitian ini. Penelitian ini juga mengisyaratkan hubugan yang positif dan signifikan dari pemberian tunjangan kinerja terhadap motivasi, artinya semakin tinggi tunjangan kinerja yang didapatkan pegawai, maka akan semakin tinggi pula motivasi kerja yang diakibatkan. Tentu dari nilai statistik yang dihasilkan masih menunjukkan adanya faktor lain yang dapat mempengaruhi motivasi.

Pengaruh dan taraf signifikansi pemberian tunjangan kinerja terhadap motivasi kerja pada penilitian terbilang tinggi. Hal ini terlihat dari koefesien korelasi sebesar 0,265 dengan nilai t-statistik sebesar 2,655 dan signifikan pada $\alpha=0,050$ nilai t-tabel sebesar 1,960. Dengan demikian, secara umum, hipotesis penelitian ini tentang pengaruh pemberian tunjangan kinerja terhadap motivasi kerja, adalah sejalan dan sesuai dengan hasil penelitian yang dilakukan para peneliti sebgaimana dipaparkan sebelumnya. Demikian pula dengan teori tentang insentif dan kompensasi yang mendukung penelitian ini, sebagaimana yang telah dijelaskan pada BAB II, diantaranya tujuan pemberian insentif adalah untuk memberikan tanggung jawab dan dorongan kepada karyawan dalam rangka meningkatkan kualitas dan kuantitas hasil kerjanya, Rivai et.al (2011).

Dari itu dapat disimpulkan bahwa tujuan pemberian insentif atau tunjangan kinerja saat ini terbukti berdampak signifikan terhadap peningkatan motivasi kerja pegawai KPU Kabupaten/Kota se-Pulau Lombok. Kebijakan pemberian tunjangan kinerja yang telah dilakukan pemerintah kepada para pegawai KPU sudah tepat sasaran yakni untuk meningkatkan motivasi dan semangat kerja para pegawai.

10.2. Pengaruh Kepemimpinan terhadap Motivasi Kerja

Terdapat lima indikator yang digunakan untuk mengukur pengaruh variabel kepemimpinan terhadap motivasi kerja, yaitu pemberian dan pembagian tugas bagi staf, perintah dan pengarahan, memberikan penghargaan dan hukman, memberikan motivasi serta melakukan pengawasan. Namun karena terdapat dua indikator yang tidak memenuhi syarat uji hipotesis, shingga dihapus. Dua indikator tersebut adalah memberikan motivasi dengan nilai outer loading 0,354 dan indikator melakukan pengawasan yang memilki nilai outer loading sebesar 0,469 .

Secara umum, kepemimpinan pada lingkup KPU Kabupaten/Kota se-pulau Lombok berdampak positif dan signifikan terhadap motivasi kerja pegawai. Hal ini mengandung arti bahwa semakin bagus kepemimpinan pada setiap satuan kerja KPU Kabupaten/Kota makan akan semakin tinggi pula motivasi pegawai di kantor setempat.

Penelitian ini, khususnya pada sub bagian tentang pengaruh peran kepemimpinan terhadap peningkatan motivasi kerja telah dapat dibuktikan dengan hasil penelitian yang menunjukkan hasil positif dan signifikan. Hasil penelitian ini sejalan dengan hasil penelitian yang dilakukan Setiawan, et.al (2012) menyimpulkan bahwa kepemimpinan berpengaruh positif dan signifikan terhadap motivasi kerja. Sambiran, et,al (2015) menyimpulkan bahwa kepemimpinan secara parsial berpengaruh positif dan signifikan terhadap motivasi kerja; 


\section{$\int M M \quad \begin{gathered}\text { JURNAL MAGISTER MANAJEMEN } \\ \text { UNIVERSITAS MATARAM }\end{gathered}$ UNRAM VOL. 6 No. 1 MARET 2017}

kepemimpinan dan insentif secara simultan berpengaruh positif dan signifikan terhadap motivasi kerja

Sebagaimana dijelaskan oleh sejumlah ahli tentang kepemimpinan; bahwa kepemimpinan adalah proses untuk memengaruhi orang lain, untuk memahami dan setuju dengan apa yang perlu dilakukan dan bagaimana tugas itu dilakukan secara efektif, serta proses untuk memfasilitasi upaya individu dan kolektif untuk mencapai tujuan bersama (Yukl 2005). Sementara menurut Robbins (2006), kepemimpinan merupakan kemampuan untuk memengaruhi suatu kelompok ke arah tercapainya suatu tujuan. Definisi kepemimpinan secara luas meliputi proses memengaruhi dalam menentukan tujuan organisasi, memotivasi perilaku pengikut untuk mencapai tujuan, memengaruhi untuk memperbaiki kelompok dan budayanya. Selain itu juga memengaruhi interpretasi mengenai peristiwa-peristiwa para pengikutnya, pengorganisasian dan aktivitas-aktivitas untuk mencapai sasaran, memelihara hubungan kerja sama dan kerja kelompok, perolehan dukungan dan kerja sama dari orangorang di luar kelompok atau organisasi (Rivai, 2004). Dalam penelitian ini, tentu peran kepemimpinan yang baik dan telah diterapkan oleh para pemimpin di lingkup KPU Kabupaten/ Kota se-pulau lombok tentu memiliki dampak positif dan signifikan dalam meningkatkan motivasi pegawai. Tingginya angka taraf signifikansi, sebagaimana dipaparkan sebelumnya menunjukkan arti pentingnya peran pemimpin dalam memberikan motivasi bagi pegawai.

10.3. Pengaruh Tunjangan Kinerja terhadap Produktivitas Kerja

Hasil analisis data menunjukkan bahwa terdapat pengaruh positif dan tidak signifikan tunjangan kinerja terhadap produktivitas. Hal ini terlihat dari hasil analisis data yang menunjukkan bahwa nilat $t$-statistik sebesar 0,952 dan tidak signifikan pada $a=0,050$. Nilai $t-$ statistik ini berada jauh di bawah nilai kritis 1,960, sehingga $\mathrm{H}_{\mathrm{a}}$ ditolak. Artinya pengaruh pemberian tunjangan kinerja terhadap produktivitas pegawai KPU Kabupaten/Kota tidak memiliki pengaruh signifikan. Banyak hal tentu yang menjadi faktor penyebab tinggi rendahnya produktivitas PNS. Hal ini tentu menjadi hal yang menarik untuk digali kembali oleh peneliti berikutnya.

Sejumlah penelitian tentang insentif berupa tunjangan dan sejenisnya telah menunjukkan hasil yang cukup beragam. Seperti penelitian yang dilakukan Achie et.al (2016), mengungkapkan bahwa meskipun karyawan menikmati beberapa insentif keuangan, namun karyawan masih tidak puas dengan insentif keuangan yang diberikan meski berpeluang untuk meningkatkan produktivitas. Dua penelitian ini terlihat jelas perbedaan yang ditunjukkan pengaruh dari variabel insentif terhadap produktivitas.

Sementara peneiliti lainnya, Hakim (2011) menyimpulkan bahwa kompensasi berpengaruh positif dan signifikan terhadap peningkatan produktivitas kerja pegawai, kompensasi dan motivasi secara simultan juga berpengaruh positif dan signifikan terhadap produktivitas kerja pegawai. Wardoyo, W.T. D., (2016) juga menyimpulkan bahwa kompensasi berpengaruh positif dan signifikan terhadap produktivitas kerja. Firmansyah, Z., (2015) menyimpulkan bahwa upah berpengaruh positif dan signifikan terhadap produktivitas kerja.

Terdapat sejumlah hasil penelitian yang telah dipaparkan sebelumnya menunjukkan hasil yang tidak signifikan dari pemberian insentif. Hasil penelitian terdahulu tersebut memiliki unsur kesamaan dalam penelitian ini. Berbeda halnya dengan pendapat yang dikemukakan Simamora (2006), bahwa tujuan utama program insentif adalah untuk mendorong dan meningkatkan produktivitas karyawan dan efektivitas biaya.

10.4. Pengaruh Kepemimpinan terhadap Produktivitas Kerja 


\section{$\int M M \quad \begin{gathered}\text { JURNAL MAGISTER MANAJEMEN } \\ \text { UNIVERSITAS MATARAM }\end{gathered}$ UNRAM VOL. 6 No. 1 MARET 2017}

Berdasarkan hasil analisis data menunjukkan bahwa terdapat pengaruh positif yang tidak signifikan dari kepemimpinan terhadap produktivitas kerja. Sebagamana hasil analisa dan uji hipotesis sebelumnya yang menunjukkan tidak adanya pengaruh yang signifikan dari variabel kepemimpinan terhadap produktivitas kerja, penelitian ini memiliki kesamaan dengan penelitian yang dilakukan Chandra et.al (2015), yang menyimpulkan bahwa; kepemimpinan berpengaruh tidak signifikan terhadap produktivitas. Sisi lain hasil penelitian ini berbeda dengan penelitian yang dilakukan Halil, et.al (2015), yang menyimpulkan bahwa: Kepemimpinan berpengaruh signifikan terhadap produktivitas kerja karyawan. Luly, et.al (2015), kepemimpinan berpengaruh positif dan signifikan terhadap produktivitas, Nasution, et,al (2016); mengatakan kepemimpinan berpengaruh positif dan signifikan terhadap produktivitas; Husain, (2015) yang menyimpulkan kepemimpinan berpengaruh positif dan signifikan terhadap produktivitas; serta Salim (2014) mengatakan bahwa: Kepemimpinan berpengaruh positif dan signifikan terhadap produktivitas.

Sedagkan dari sisi teoritis, sebagaimana diungkapan Siagian (1997) bahwa peranan para pemimpin dalam organisasi sangat sentral dalam pencapaian tujuan dari berbagai sasaran yang ditetapkan sebelumnya. Perilaku kepemimpinan memiliki kecenderungan pada dua hal yaitu konsiderasi atau hubungan dengan bawahan dan struktur inisiasi atau hasil yang dicapai. Kecenderungan kepemimpinan menggambarkan hubungan yang akrab dengan bawahan misalnya bersikap ramah, membantu dan membela kepentingan bawahan, bersedia menerima konsultasi bawahan dan memberikan kesejahteraan.

\subsection{Pengaruh Motivasi Kerja terhadap Produktivitas Kerja}

Hasil analisa data menunjukka bahwa motivasi kerja memiliki pengaruh yang positif dan signifikan terhadap produktivitas kerja. Nilai t-statistik jauh di atas nilai kritis, yakni nilai koefisien sebesar 0,684 dengan nilat t-statistik sebesar 9,494 dan signifikan pada $\alpha=0,050$ serta nilai t-statistik berada di atas nilai kritis 1,960.

Sebagaimana telah disimpulkan dari hasil uji hipotesis, bahwa motivasi berpengaruh positif dan signfikan terhadap produktivitas kerja pegawai KPU Kabupaten/Kota se-pulau Lombok. Hasil penelitian sejalan dengan penelitian yang telah dilakukan Assagaf et.al (2015), yang menyimpulkan bahwa: 1) Motivasi secara parsial berpengaruh signifikan terhadap Produktivitas Kerja, 2) Disiplin, Motivasi, dan Semangat Kerja secara simultan berpengaruh signifikan terhadap Produktivitas Kerja. Halil, (2015) juga menyimpulkan bahwa motivasi berpengaruh positif dan signifikan terhadap porduktivitas; Luly, (2015) juga menyimpulkan demikian, bahwa motivasi berpengaruh positif dan signifikan terhadap porduktivitas; demikian pula dengan Salim, (2014) yang menyimpulkan bahwa motivasi berpengaruh positif dan signifikan terhadap porduktivitas; Hendratmoko, (2013) juga menyimpulkan yang sama bahwa motivasi berpengaruh positif dan signifikan terhadap porduktivitas. Berbeda dengan penelitian yang dilakukan Elqadri et.al (2015), bahwa motivasi tidak berpengaruh signifikan terhadap produktivitas kerja. Hasil penelitian yang dilakukan dua peneliti di atas memunculkan perbedaan hasil penelitian dari variabel yang ada. Perbedaan tersebut memungkinkan hasil yang tidak sama meski diberikan perlakuan yang sama.

Hasibuan (1999) menjelaskan bahwa motivasi adalah suatu perangsang keinginan dan penggerak kemauan bekerja sesorang karena setiap motif mempunyai tujuan tertentu yang ingin dicapai. Pendapat senada diungkapkan Siagian (1995) menjelaskan bahwa motivasi adalah keadaan kejiwaan yang mendorong, mengaktifkan atau menggerakkan, mengarahkan dan menyalurkan perilaku, sikap serta tindakan seseorang yang selalu dikaitkan dengan pencapaian tujuan, baik tujuan organisasi maupun pribadi masing-masing anggota. 


\section{JMM UNRAM VOL. 6 No. 1 MARET 2017}

10.6. Pengaruh Tunjangan Kinerja terhadap Produktivitas Kerja melalui Mediasi Motivasi Kerja.

Besarnya pengaruh tidak langsung variabel tunjangan kinerja terhadap produktivitas pegawai KPU Kabupaten/ Kota se-pulau Lombok dengan mediasi variabel motivasi kerja dapat dilihat dari hasil olah data pada indirect effect untuk pengaruh tunjangan kinerja terhadap produktivitas melalui motivasi menunjukkan adanya hubungan yang positif dengan nilai koefisien sebesar 0,182 dengan nilat t-statistik sebesar 2,423 dan signifikan pada $a=$ 0,050. Nilai t-statistik tersebut berada di atas nilai kritis 1,960, dengan demikian $\mathrm{H}_{\mathrm{a}}$ diterima. Hipotesis yang menjelaskan adanya pengaruh tunjangan kinerja melalui motivasi terhadap terhadap produktivitas adalah diterima.

Nilai t-statistik sebesar 2,423 melebihi nilai kritis yakni 1,960. Selisih kedua angka tersebut tidak begitu besar. Namun demikian tetap, memiliki dampak yang positif dan signifikan. Artinya peran tunjangan kinerja dalam meningkatkan produktivitas pegawai di lingkup KPU Kabupaten/Kota yang ada di pulau Lombok melalui motivasi menjadi faktor penting dalam menetukan tinggi rendahnya produktivutas.

Variabel mediator juga disebut variabel intervening atau variabel proses. Jika variabel independen tidak lagi mempunyai pengaruh terhadap variabel dependen setelah mengontrol variabel mediator, maka dinyatakan terjadi perfect atau complete mediation. Jika pengaruh variabel independen terhadap variabel dependen berkurang tetapi masih berbeda dari 0 , setelah mengontrol variabel mediator, maka dinyatakan terjadi partial mediation (Kenny, 2008).

Mengacu pada teori sebelumnya, bila dilihat dari hasil uji pengaruh langsung dari tunjangan kinerja terhadap produktivitas yang menunjukkan hasil positif dan tidak signifikan, maka dalam pengaruh tidak langsung ini tentu peran motivasi sebagai penengah atau mediatorlah yang sangat menetukan. Artinya, peran motivasi mediator ini masuk pada kategori mediasi penuh atau complete mediation. Ini dapat juga dilihat dari tingginya pengaruh hububungan langsung dari tunjangan kinerja terhadap motivasi. Seperti yang penelitian dilakukan Rachmawati (2011), Kompensasi berpengaruh tidak langsung terhadap kinerja melalui motivasi kerja, sehingga dapat disimpulkan bahwa motivasi kerja menjadi variabel yang memediasi antara kompensasi terhadap kinerja karyawan. Dari hasil penelitian tersebut dapat disimpulkan bahwa semakin banyak tunjangan kinerja yang akan diberikan, maka akan berdampak semakin tinggi pula motivasi dan produktivitas kerja pegawai.

10.7. Pengaruh Kepemimpinan terhadap Produktivitas Kerja melalui Mediasi Motivasi Kerja.

Hasil dari pengaruh tidak langsung variabel kepemimpinan terhadap produktivitas pegawai KPU Kabupaten/ Kota se-pulau Lombok dengan mediasi variabel motivasi kerja dengan nilai koefisien sebesar 0,264 dengan nilat t-statistik sebesar 4,269 dan signifikan pada a $=0,050$ dan nilai t-statistik tersebut berada di atas nilai kritis 1,960, dengan demikian $H_{a}$ diterima. Hasil penelitian ini menunjukkan pengaruh tidak langsung yang bernilai positif dan berdampak signifikan dari peran kepemipinan melalui motivasi terhadap produktivitas. Sebagaimana pada pembahasan sebelumnya, peran mediasi motivasi dari kempimpinan terhadap produktivitas ini masuk pada kategori mediasi penuh atau complete mediation. Mengingat pengaruh lagsung dari variabel kepemimpinan terhadap produktivitas positif dan tidak signfikan.

Pengaruh tidak langsung dari kepemimpinan melalui mediasi motivasi terhadap produktivitas sebagaimana hasil olah data pada penelitian ini menunjukkan bahwa peran mediasi motivasi sangat menentukan. Tanpa adanya motivasi kerja yang bagus dari pegawai, maka tingkat produktivitas pegawai akan tetap rendah bila hanya ditopang dengan 


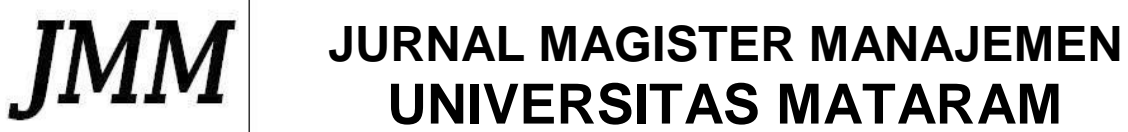

kepemimpinan. Namun demikian, hubungan positif yang ditunjukkan pada penelitian masih memberikan peluang bagi variabel kepemimpinan untuk menjadi lebih bermakna atau berpengaruh signifikan terhadap produktivitas pegawai. Tentu, bila semakin bagus gaya kepemimpinan di tiap kantor KPU Kabupaten/Kota akan membawa dampak yang positif dan signifikan terhadap motivasi dan produktivitas pegawai.

\section{KESIMPULAN}

Berdasarkan hasil penelitian pada responden pegawai KPU Kabupaten/Kota se-pulau Lombok maka dapat disimpulkan beberapa hal sebagai berikut ini :

1) Tunjangan Kinerja berpengaruh positif dan signifikan terhadap motivasi kerja.

2) Kepemimpinan berpengaruh positif dan signifikan terhadap motivasi kerja.

3) Tunjangan Kinerja berpengaruh positif dan tidak signifikan terhadap produktivitas kerja.

4) Kepemimpinan berpengaruh positif dan tidak signifikan terhadap produktivitas kerja.

5) Motivasi kerja berpengaruh positif dan signifikan terhadap produktivitas kerja.

6) Tunjangan Kinerja berpengaruh positif dan signifikan terhadap produktivitas kerja melalui peran mediasi motivasi kerja.

7) Kepemimpinan berpengaruh positif dan signifikan terhadap produktivitas kerja melalui peran mediasi motivasi kerja.

\section{SARAN}

Berdasarkan pembahasan dan simpulan yang telah dikemukakan sebelumnya, maka saran dari penelitian ini adalah sebagai berikut:

1) Mempertahankan motivasi dan produktivitas kerja pegawai KPU Kabupaten/Kota sepulau Lombok, maka bagi pemimpin di tiap satuan kerja agar meningkatkan model kepemimpinan menjadi lebih bagus.

2) Sementara untuk pemerintah, perlu meninjau kemabali kebijakan terkait pemberian tunjangan kinerja.

3) Bagi para pegawai KPU Kabupaten/Kota se-pulau Lombok agar dapat menerima realitas yang terdapat di kantor masing-masing. Kesenjangan pemberian tunjangan kinerja dari tiap tingkatan agar tidak dijadikan masalah serius dalam meningkatkan semangat kerja sehingga motivasi dan produktivitas kerja semakin meningkat.

4) Penelitian ini masih terdapat perbedaan dan kesenjangan dengan peneilitian yang lain.

\section{DAFTAR PUSTAKA}

Achie,T.S., Kurah,T.J., (2016), The Role of Financial Incentives as a Motivator in Employee's Productivity in Nigeria Electricity Distribution Companies. International Journal of Research in Studi Bisnis dan Manajemen Vol.3, No.1, pp.1-8

Assagaf, S.C.Y., Dotulong, L.O.H., (2015), Pengaruh Disiplin, Motivasi dan Semangat Kerja terhadap Produktivitas Kerja Pegawai Dinas Pendapatan Daerah Kota Manado. Jurnal EMBA, Vol.3, No.2, pp. 639-649.

Bass, B.M \& Avolio, (1993), Transformational Leadership and Organizational Culture. Public Administration Quarterly

Bass, B.M., B.J. Avolio, D.I Jung \& Y. Berson (2003), Predicting Unit Performance by assessing transformational and transactional leadership. Journal of Applied Psychology, Vol.88, No. 2, pp. 207-218

Chandra,A., Prasetya,W., (2015), Peningkatan Produktivitas melalui Peningkatan Kualitas Kerja, Kepemimpinan, dan Kompensasi pada PT. KMK Global Sports. E-Journal Widia Ekonomika, Vol.1, No.1, pp58-63. 


\section{JMM UNRAM VOL. 6 No. 1 MARET 2017}

Dessler, Garry, (2007), Manajemen Sumber Daya Manusia, buku 1 \& 2, Jakarta : Penerbit Indeks.

Dotulong.H.OL., Sambiran.B., Sepang.J., (2014), Pengaruh Kepemimpinan dan Insentif Finansial terhadap Motivasi Kerja Karyawan pada PT. Adira Finance Manado. Jurnal EMBA Vol.3, No.3, 2015. ISSN 2303-11

Elqadri,M.Z., Wardoyo,W.T.D., Priyono, (2015), The Influence of Motivation and Discipline Work against Employee Work Productivity Tona'an Markets, Review of European Studies, Vol.7, No.12, pp59-66.

Firmansyah.Z., (2015), Analisis Pengaruh Umur, Pendidikan, dan Upah terhadap Produktivitas Tenaga Kerja pada Mitra Kerja Industri Rambut di Kabupaten Purbalingga. Economics Development Analysis Journal, Vol.4, No.1, pp. 81-88.

Fuad Mas'ud, (2004), Survai Diagnosis Organisasional (Konsep dan Aplikasi), Badan Penerbit Universitas Diponegoro.

Ghozali, L., dan Lantan, H., 2012, Partial Least Square ; Konsep, Teknik dan aplikasi smartPLS 2.0 M3, Semarang. Univeristas Diponegoro.

Halil, Yudhia, K.B.P., Kustiari, T., (2015), Pengaruh Kepemimpinan, Kedisiplinan dan Motivasi Kerja terhadap Produktivitas melalui Kinerja Karyawan (Studi Empiris Pada Perusahaan Daerah Perkebunan (PDP) Kabupaten Jember). JEAM, Vol.XIV, pp. 49-70.

Handoko,T.Hani, (2001), Manajemen Personalia Dan Sumber Daya Manusia (Edisi 2), Yogyakarta : Badan Penerbit Fakultas Ekonomi.

Hardiyana.A., Iskandar.S., Nurlaila.L., (2013), Pengaruh Budaya Organisasi dan Kompensasi Terhadap Motivasi Kerja serta Implikasinya Terhadap Kinerja Guru. Jurnal Ekonomi, Bisnis \& Entrepreneurship Vol. 7, No. 2, Oktober 2013, 64-73 ISSN 2443-0633.

Hasibuan. Melayu S.P, (2001), Manajemen Sumber Daya Manusia, Jakarta : PT. Bumi Aksara.

Kenny, DA, (2008) Organizational Research Methods. Volume 11 Number 2 April 2008 353358 (C) 2008 Sage Publications.

KPU RI, (2015), Buku Besar Regulasi Petunjuk Pelakasanaan Pemilu dan Peyenyelanggara Pemilu.

Luly, R.J., Sepang, J.L., (2015), Analisis Metode Kepemimpinan dan Motivasi Kerja terhadap Peningkatan Produktivitas Kerja Pegawai di Kantor Balai Pelatihan Kesehatan Provinsi Sulawesi Utara. Jurnal EMBA, Vol.3, No.3, pp. 744-756

Mangkunegara, Prabu, (2002), Manajemen Sumber Daya Manusia Perusahaan, Cetakan ke-2. Bandung: PT. Remaja Rosdakarya Offset.

Mankiw, N. G., (2003), Pengantar Ekonomi Makro 1. Jakarta : Salemba Empat. (2006), Pengantar Ekonomi Makro 11. Jakarta : Salemba Empat.

Nasution, P.A., Mahargiono, B.P., Soesatyo, Y., (2016), Effect of Leadership Styles, Organizational Climate and Ethos of Work on Employee Productivity (PT. HP Metals Indonesia the Powder Coating) International Journal of Business and management, Vol.11, No.2, pp. 262273.

Ndraha, T. (2002), Pengantar Teori Pengembangan Sumber Daya Manusia. Jakarta: Rineka Cipta.

Noor.J., (2014), Analisis Data Penelitian Ekonomidan Manajemen. PT Gramedia Jakarta.

Ojeifo, S. A, Ekpudu, Jonathan, (2014), Financial Incentives and Rewards on Employee Motivation in the Nigerian Electricity Distribution Company. European Journal of Business and Management. Vol.6, No.2, 2014 ISSN 2222-1905 (Paper) ISSN 2222-2839 (Online).

Rachmawati K. (2011), Analisis Kinerja Karyawan Ditinjau dari Kompensasi dan Motivasi Kerja sebagai Variabel Intervining pada PG. Soedhono Ngawi. MEDIA SOERJO. ISSN 1979 6239. Vol. 8 No. 1 April 2011.

Rivai ,Veithzal dan Ella Jauvani, (2004), Manajemen Sumber Daya Manusia untuk Perusahaan. Jakarta, Rajawali Pers 


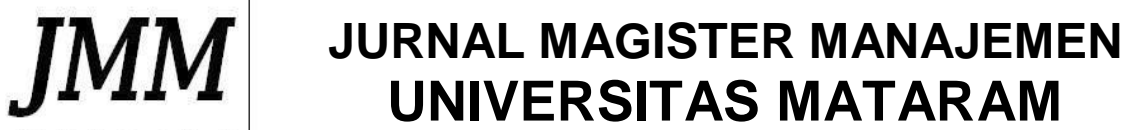 UNRAM VOL. 6 No. 1 MARET 2017}

Robbins, S.P., (2003), Perilaku organisasi, konsep, kontroversi, aplikasi. PT. Prenhallindo, Jakarta. ----, (2006), Perilaku organisasi, konsep, kontroversi, aplikasi. PT. Prenhallindo, Jakarta Siagian, S.P., (1995), Teori Motivasidan Aplikasinya, Jakarta :Rineka Cipta. -, (2010), Manajemen Sumber Daya Manusia. Jakarta: PT. Bumi Aksara.

Simamora, H., (1997), Manajemen Sumber Daya Manusia Edisi Kedua. Yogyakarta: STIE YKPN. -------, (2006), Manajemen Sumber Daya Manusia Edisi III. Yogyakarta: Sekolah Tinggi Ilmu Ekonomi YKPN.

Simanjuntak, Payaman J., (2001), Pengantar Ekonomi Sumber Daya Manusia. Jakarat : LPPE UI Sinungan, M., (2005), Produktivitas Apa dan Bagaimana. Jakarta : Bumi Putera.

Sinaga, (2010), Pengaruh Gaya Kepemimpinan Transformasional dan Gaya Kepemimpinan Transaksional terhadap Produktivitas Karyawan dengan Motivasi sebagai Intervening Variabel (Studi Pada Karyawan CV Cahaya Setia Mulia Yogyakarta). E-journale.

Sugiyono, (2010), Metode Penelitian Administrasi. Alfabeta. Bandung.

Suryani, Devi, (2012), Hubungan Pemberian Insentif Terhadap Kinerja Agen Penjualan Polis Asuransi Pada PT. Asuransi Bintang Tbk Cabang Pekan Baru). Thessis Diakses September 2012.

Sutrisno, E., (2015), Manajemen Sumber Daya Manusia. Jakarta: Kencana Prenada Media Group. Usmara, (2002), Paradigma Baru Manajemen Sumber Daya Manusia. Yogyakarta.Amara Books.

Wardoyo, W.T.D., (2016), The Influence of the Discipline and Compensation against Work Productivity (Study on the Security Services Company, PT Garuda Milky Artha Surabaya). International Journal of Business and Management; Vol. 11, No. 1.pp. 64-72.

Wibowo, (2011), Manajemen Kinerja-Edisi ketiga. Jakarta: PT. Raja grafindo Persada.

Yammarino, F.J., W.D. Spangler \& B.M. Bass, (1993), "Transformational leadership and performance: A longitudinal investigation", Leadership Quarterly, Vol.4, No.1, pp. 81-102

Yukl, Gary, (2005), Kepemimpinan dalam Organisasi. Edisi Kelima. PT. Indeks, Jakarta.

Zainun, (1979), Manajemen dan Motivasi. Jakarta. Balai Putsaka. 